\title{
Genetic variability and correlation studies for biochemical traits in Brassica juncea
}

L.

Fawad Ali ${ }^{1}$, Junaid Khan ${ }^{2}$, Haneef Raza ${ }^{2 *}$, Ijaz Naeem ${ }^{3}$, Murad Khan ${ }^{4}$, Naila Nawaz Khan ${ }^{4}$, Anwar Rashid ${ }^{5}$, Mohammad Wasiullah Khan ${ }^{5}$, Jawad $\mathrm{Ali}^{2}$ and Abdul Saboor Khan ${ }^{2}$

1. Department of Plant Breeding and Genetics, The University of Agriculture, Peshawar-Pakistan

2. Department of Agriculture, The University of Swabi, Swabi-Pakistan

3. Instituite of biotechnology and genetic engineering, Peshawar-Pakistan

4. Department of Agriculture, The University of Haripur-Pakistan

5. Department of Horticulture, The University of Agriculture, Peshawar-Pakistan

*Corresponding author's email: rhanif5@gmail.com

Citation

Fawad Ali, Junaid Khan, Haneef Raza, Ijaz Naeem, Murad Khan, Naila Nawaz Khan, Anwar Rashid, Wasi Ullah Khan, Jawad Ali and Abdul Saboor Khan. Genetic variability and correlation studies for biochemical traits in Brassica juncea L. Pure and Applied Biology. Vol. 6, Issue 1, pp72-78.

http://dx.doi.org/10.19045/bspab.2016.50168

Received: 05/07/2016 Revised: 13/12/2016

Accepted: 18/12/2016

Online First: 29/12/2016

\section{Abstract}

Brassica juncea germplasm was evaluated to estimate divergence, associations among traits and heritability for various bio-chemical traits in RCB design having three replications at the University of Agriculture, Peshawar during 2011-12. Data were recorded on six bio-chemical traits viz., oil content, erucic acid content, glucosinolate content, protein content, oleic acid content and linolenic acid content. Highly significant variations were recorded for all the studied bio-chemical traits. Maximum heritability was observed for glucosinolate content $(0.90)$, protein content (0.80) and erucic acid content (0.82), whereas moderate heritability was recorded for oil content (0.54), oleic acid content (0.33) and linolenic acid (0.43). The high heritability was coupled with appreciable selection response. Negative associations were recorded among oil content and protein content $\left(\mathrm{r}=-0.419^{* *}\right)$. Protein content showed positive associations with glucosinolate content $\left(\mathrm{r}=0.678^{* *}\right)$ and erucic acid content $\left(\mathrm{r}=0.481^{* *}\right)$.

Keywords: Brassica Juncea L.; Heritability; Correlation; Selection response

\section{Introduction}

Brassica belongs to family Brassicaceae, an important genera of this group [1]. Family Brassicaceae consists of about 338 genera and 3709 species [2]. Brassica juncea generally known as Indian mustard is cultivated on about $70 \%$ of the area devoted to rapeseed and mustard. Brassica juncea is an important species among the six most cultivated species of brassica worldwide. The most suited qualities of Brassica juncea are early ripening, pest resistance, heat tolerance and non-shattered pods. Cultivation of Brassica juncea cultivar are reducing day by day due low seed yield and is one of the most dangerous threat to it.

Pakistan spent a huge amount of money on oil import after petroleum. It could be only 
saved by producing oilseed cultivars having high yield and better quality [3]. To fulfill the demand and needs of future oil consumption of Pakistan, the oilseed having high quality must be one of the key objectives of brassica breeding $[4,5]$. Both conventional and genetic engineering methods are used to improve quality traits of brassica. Correlation analysis is a useful tool to determine the relationship between different pairs of traits. In the genetic context, there is little likelihood of separate control for any pair of characters [6]. Genetic divergence, heritability and associations among traits are important to develop effective criteria for selection in a breeding programs [6-8]. New cultivars development with better performance is the paramount goal of a plant breeder in a breeding program. To run an effective breeding program, the available local germplasm must be evaluated for variability and heritability to know their actual potential. These local germplasms will be used as a source to design a breeding programme [9].

\section{Materials and methods}

Brassica juncea germplasm was evaluated to estimate divergence, associations among traits and heritability for various biochemical traits in RCB design with three replications at the University of Agriculture, Peshawar during 2011-12. Row length was 5 meter while distance between adjacent rows and plants were 30 and $20 \mathrm{~cm}$, respectively. Each entry had two rows per genotype in a replication. Total area of the experiment was $9 \mathrm{~m} 2$. Ten plants were selected for data recording per genotype in each replication.

\section{Statistical analysis}

MSTAT-C computer software was used for the analysis. Broad sense heritability was estimated from their expected means squares [10]. Components of variance including genotypic, phenotypic and error variances were computed according to [11].
Genetic variance $=\mathrm{Vg}=(\mathrm{GMS}-\mathrm{EMS}) / \mathrm{r}$

Environmental variance $=\mathrm{Ve}=\mathrm{EMS}$

Phenotypic variance $=\mathrm{Vp}=\mathrm{Vg}+\mathrm{Ve}$

Heritability $=h^{2}{ }_{B S}=V g / V p$

Selection response was determined using the following formula [12].

$$
R e=k \times \sqrt{V p} \times h^{2}
$$

Where;

$\mathrm{K}=\mathrm{A}$ constant value at a specific selection intensity, k=1.40@20\%.

\section{Results and discussion}

An oilseed having high oil content with better quality is the end goal of each grower. Analysis of variance showed highly significant $(P \leq 0.01)$ differences for oil content [13, 14] (Table 1). Oil content ranged from 43.60 to $50.70 \%$. Maximum oil content was observed in genotype 619 $(50.70 \%)$ followed by genotypes 618 (50.60 $\%), 616(50.20 \%), 615(49.80 \%)$. Whereas minimum values were found in genotype $610(43.60 \%)$ followed by $606(45.00 \%)$, $611(45.80 \%)$ and $608(46.10 \%)$ (Table 2). Genetic variance (2.88) was greater than environmental variance (2.47) for oil content. Moderate broad sense heritability (0.54) and the selection response (1.74) were recorded for said trait, which suggested that genetic variance could play an important role in the inheritance and improvement of the said trait (Table 3). However high magnitude of heritability (bs) for oil percent were recorded in rapeseed [15]. Oil content showed highly significant negative correlation with protein content $(\mathrm{r}=$ $\left.0.419^{* *}\right)$, whereas non-significant with rest of the traits (Table 4).These findings are in conformity with $[14,16,17]$ who observed negative correlations among oil content and protein content. However, [18] reported positive associations among oil content and protein content.

For protein content highly significant $(P \leq 0.01)$ differences were observed (Table 1).Our findings are similar with the results of $[6,19]$. They noted significant differences 
for protein content in Brassica napus and Brassica juncea. The ranges for the mean were 26.20 to $20.6 \%$ for protein content. Maximum $(26.20 \%)$ protein content was observed in genotype 606 followed by genotypes 605 (25.60\%), $608(25.20 \%)$, $610(25.00 \%)$. Whereas minimum protein content $(20.60 \%)$ was revealed by genotype 615 , this genotype was found at par with $603(20.80 \%), 601$ and 617 both with the mean value of $21.60 \%$ (Table 2). Genetic variance (2.33) was greater in magnitude than environmental variance (0.58) for protein content. High heritability (bs) and the selection response 0.80 and 1.91 found in protein content, respectively (Table 3). These results suggested that genetic variance could play an important role in the inheritance and improvement of the said trait. Similarly, high heritability with high selection response was also reported by [6] during his study of rapeseed. While low heritability was observed by [14] in brassica for the said trait. Protein content showed highly significant positive correlation with glucosinulate content $(\mathrm{r}=0.678 * *)$ and erucic acid content $\left(\mathrm{r}=0.481^{* *}\right)$ (Table 4$)$. [20] reported positive correlation among protein content, glucosinolate content, erucic acid content, oleic acid content and linolenic acid content which confirmed our findings.

Highly significant $(P \leq 0.01)$ variations were recorded from ANOVA (Table 1) for glucosinolates and the mean values varied between 107.40 to $144.40\left(\mu \mathrm{gMg}^{-1}\right)$. [21, 22] supported our findings by reporting highly significant variations for the said trait. Significant variations were also observed among the studied brassica genotypes [23]. Maximum glucosinolate content was observed in genotype $608\left(144.40 \mu \mathrm{gMg}^{-1}\right)$. This genotype was found equal in performance with $605\left(143.10 \mu \mathrm{gMg}^{-1}\right), 606$ $\left(139.20 \mu \mathrm{gMg}^{-1}\right)$ and $610\left(133.40 \mu \mathrm{gMg}^{-1}\right)$. However minimum values performance was shown by genotypes $611\left(107.40 \mu \mathrm{gMg}^{-1}\right)$ followed by $617 \quad\left(110.60 \mu \mathrm{gMg}^{-1}\right), \quad 604$ $\left(117.00 \mu \mathrm{gMg}^{-1}\right)$ and $615\left(117.80 \mu \mathrm{gMg}^{-1}\right)$ (Table 2). Genetic variance (93.03) was greater than environmental variance (9.69) for glucosinolate content. High broad sense heritability (0.91) with maximum selection response (12.85) was computed for glucosinolates, which suggested that the inheritance and improvement of the said trait could be due to genetic variance (Table 3 ). High heritability for glucosinolate content with moderate selection response was in similarity with the findings of [14, 24]. Glucosinulate content revealed highly significant positive correlation with erucic acid content $\left(\mathrm{r}=0.377^{*} *\right)$, while nonsignificant correlation was revealed with rest of the traits (Table 4). Positive correlation among glucosinolate content, linolenic acid content and erucic acid content were observed [14].

Highly significant $(P \leq 0.01)$ differences were resulted for oleic acid content (Table 1) which were further strengthened by the results of [14] who also reported significant variations among different genotypesoleic acid content ranged from 33.30 to $39.80 \%$. Maximum oleic acid content was observed in genotype $603(39.80 \%)$ followed by genotypes $601(39.50 \%), 619(38.90 \%)$ and $610(38.70 \%)$. Whereas minimum values were found in genotype $609(33.30 \%)$ followed by $615(34.20 \%), 605(35.30 \%)$ and $614(35.40 \%)$ (Table2). Genetic variance (1.88) was smaller than environmental variance (3.71) for oleic acid content. Moderate broad sense heritability (0.34) and the selection response $(1.11 \%)$ were recorded for said trait (Table 3). However, our findings are discouraged by [25] who estimated high heritability with high selection response. Oleic acid content showed non-significant positive correlation with linolenic acid content $(r=0.011)$ and erucicacid content $(r=0.159)$ (Table 4). [26] negative correlation between linolenic acid 
content andoleic acid content which is in dissimilarity to our results.

For linolenic acid content manifested highly significant $(P \leq 0.01)$ differences (Table 1) and ranged between 9.60 to $12.00 \%$. Our results are in agreement with the result of $[14,6]$. They also reported significant differences for linolenic acid in brassica genotypes. Highly significant variations were also observed by [27] for the said trait. Maximum linolenic acid content $(11.80 \%)$ was observed in genotype 603 and was found at par with genotypes 606(11.70\%) and 602 (11.60\%). However minimum values were found in genotype $610(9.60 \%)$ and were found in performance equal with 611 (9.90 \%), 614 (10.20\%); while genotypes 613, 615 and 617exhibited same mean value of $10.30 \%$ (Table 2). Genetic variance (0.35) was lower than environmental variance (0.46) for linolenic acid content. Moderate broad sense heritability $(0.43)$ and the selection response $(0.54 \%)$ were recorded for said trait (Table $3)$. However, contrasted results have been reported by [6] having high heritability with moderate selection response Linolenic acid content showed non-significant positive correlation with all the studied traits (Table 4). Positive correlations were reported among glucosinolate content, protein content, linolenic acid content, protein content and erucic acid content by $[28,18]$. [29] reported contrast results by negative associations between oil content and linolenic acid content.
Highly significant $(P \leq 0.01)$ differences were observed for erucic acid content from analysis of variance (Table 1). The findings of $[30,14]$ are in similarity to our results by reporting significant variations for erucic acid content. Erucic acid content ranged from 30.10 to $65.80 \%$. Maximum erucic acid content was observed in genotype 605 $(65.80 \%)$ followed by genotypes $602(62.30$ $\%), 600$ (60.90\%), 612, 616 and 620 (60.80 $\%)$. Whereas minimum values were found in genotype $615(30.10 \%)$ followed by 603(50.00\%), $617(55.00 \%)$ and 601 $(56.20 \%)$ (Table 2). Genetic variance (49.60) was greater than environmental variance (10.74) for erucic acid content. High broad sense heritability (0.82) and the selection response (8.94) were recorded for said trait, which suggested that genetic variance could be helpful in the inheritance and improvement of the said trait (Table 3). These observations are in similarity with the findings of [31]. They estimated high broad sense heritability for erucic acid content in Brassica juncea. Erucic acid content showed highly significant positive correlation with protein content $(\mathrm{r}=0.481 * *)$ and glucosinlate content $(\mathrm{r}=0.377 * *)$, whereas non-significant with rest of the traits (Table 4). Our results are similar with the result of [23]. He suggested that some of the linked parameters i.e. protein content, glucosinolate content and erucic acid content showed significantly positive associations among each other.

Table 1. Mean squares table of brassica genotypes evaluated for some important biochemical traits during 2011-12

\begin{tabular}{|l|l|l|l|c|}
\hline Traits & Replications & Genotypes & Error & CV \% \\
\hline Oil content & 2.118 & $11.092^{* *}$ & 2.465 & 3.26 \\
\hline Protein content & 4.245 & $7.567^{* *}$ & 0.579 & 3.31 \\
\hline Glucosinolates content & 176.663 & $288.776^{* *}$ & 9.691 & 2.47 \\
\hline Oleic acid content & 88.35 & $9.343^{* *}$ & 3.711 & 5.21 \\
\hline Linolenic acid content & 0.206 & $1.517^{* *}$ & 0.464 & 6.34 \\
\hline Erucic acid content & 110.382 & $159.525^{* *}$ & 10.736 & 5.64 \\
\hline
\end{tabular}


Table 2. Mean squares table of brassica genotypes evaluated for some important bio-chemical traits during 2011-12

\begin{tabular}{|c|c|c|c|c|c|c|c|}
\hline S.NO & Codes & $\begin{array}{l}\text { Oil } \\
\text { content } \\
(\%)\end{array}$ & $\begin{array}{c}\text { Protein } \\
\text { content } \\
(\%)\end{array}$ & $\begin{array}{c}\text { Glucosinolate } \\
\text { content } \\
\left(\mu \mathrm{gMg}^{-1}\right)\end{array}$ & $\begin{array}{c}\text { Oleic acid } \\
\text { content }(\%)\end{array}$ & $\begin{array}{c}\text { Linolenic } \\
\text { acid content } \\
(\%)\end{array}$ & $\begin{array}{l}\text { Erucic acid } \\
\text { content }(\%)\end{array}$ \\
\hline 1 & 600 & 48.9 & 23.2 & 128.7 & 35.9 & 11.4 & 60.9 \\
\hline 2 & 601 & 49.7 & 21.6 & 132.1 & 39.5 & 10.5 & 56.2 \\
\hline 3 & 602 & 48.1 & 22.7 & 124.1 & 35.7 & 11.6 & 62.3 \\
\hline 4 & 603 & 49.6 & 20.8 & 119.0 & 39.8 & 12.0 & 50.0 \\
\hline 5 & 604 & 49.7 & 21.9 & 117.0 & 36.0 & 10.3 & 60.0 \\
\hline 6 & 605 & 48.3 & 25.6 & 143.1 & 35.3 & 11.5 & 65.8 \\
\hline 7 & 606 & 45.0 & 26.2 & 139.2 & 37.5 & 11.8 & 58.8 \\
\hline 8 & 608 & 46.1 & 25.2 & 144.4 & 36.9 & 11.2 & 60.9 \\
\hline 9 & 609 & 48.4 & 22.6 & 118.0 & 33.3 & 11.7 & 60.4 \\
\hline 10 & 610 & 43.6 & 25.0 & 133.4 & 38.7 & 9.6 & 59.1 \\
\hline 11 & 611 & 45.8 & 22.8 & 107.4 & 37.7 & 9.9 & 57.5 \\
\hline 12 & 612 & 48.3 & 23.5 & 125.2 & 36.5 & 9.9 & 60.8 \\
\hline 13 & 613 & 48.6 & 22.8 & 122.8 & 35.7 & 10.3 & 60.1 \\
\hline 14 & 614 & 48.2 & 24.4 & 130.5 & 35.4 & 10.2 & 60.6 \\
\hline 15 & 615 & 49.8 & 20.6 & 117.8 & 34.2 & 10.3 & 30.1 \\
\hline 16 & 616 & 50.2 & 22.6 & 125.1 & 38.4 & 10.6 & 60.8 \\
\hline 17 & 617 & 46.5 & 21.6 & 110.6 & 37.9 & 10.3 & 55.0 \\
\hline 18 & 618 & 50.6 & 21.7 & 123.5 & 38.5 & 10.4 & 60.4 \\
\hline 19 & 619 & 50.7 & 21.8 & 129.4 & 38.9 & 10.9 & 60.7 \\
\hline 20 & 620 & 48.0 & 23.7 & 131.2 & 37.2 & 10.6 & 60.8 \\
\hline \multicolumn{2}{|c|}{$\operatorname{LSD}_{(0.05)}$} & 2.595 & 1.257 & 5.146 & 3.184 & 1.126 & 5.416 \\
\hline
\end{tabular}

Table 3. Genetic variance, environmental variance, heritability and selection response of various brassica genotypes

\begin{tabular}{|l|c|c|c|c|c|}
\hline Traits & $\mathbf{V g}$ & $\mathbf{V e}$ & $\mathbf{V p}$ & $\boldsymbol{h}^{\mathbf{2}}$ & $\mathbf{R}_{\mathbf{e}} \mathbf{( 2 0 \% )}$ \\
\hline Oil content & 2.876 & 2.465 & 5.341 & 0.538 & 1.742 \\
\hline Protein content & 2.329 & 0.579 & 2.908 & 0.801 & 1.912 \\
\hline Glucosionalte content & 93.028 & 9.691 & 102.719 & 0.906 & 12.850 \\
\hline Oleic acid content & 1.877 & 3.711 & 5.588 & 0.336 & 1.112 \\
\hline Linolenic acid content & 0.351 & 0.464 & 0.815 & 0.431 & 0.544 \\
\hline Erucic acid content & 49.596 & 10.736 & 60.332 & 0.822 & 8.939 \\
\hline
\end{tabular}

$\mathrm{Vg}=$ Genotypic variance; $\mathrm{Ve}=$ Environmental variance; $\mathrm{Vp}=$ Phenotype variance; $\mathrm{h}^{2}=$ Heritability; $\mathrm{Re}=$ Selection response

Table 4. Correlations among six bio-chemical traits of various brassica genotypes tested during 2011-12

\begin{tabular}{|l|l|l|l|l|l|l|}
\hline Traits & $\begin{array}{l}\text { Oil } \\
\text { content }\end{array}$ & $\begin{array}{l}\text { Protein } \\
\text { content }\end{array}$ & Glucosinolates & $\begin{array}{l}\text { Oleic acid } \\
\text { content }\end{array}$ & $\begin{array}{l}\text { Linolenic } \\
\text { acid }\end{array}$ & $\begin{array}{l}\text { Erucic } \\
\text { acid }\end{array}$ \\
\hline Oil content & 1 & $-0.419^{* *}$ & -0.129 & 0.040 & 0.158 & -0.052 \\
\hline Protein content & & 1 & $0.678^{* *}$ & 0.066 & 0.106 & $0.481^{* *}$ \\
\hline Glucosinolates & & & 1 & 0.179 & 0.225 & $0.377^{* *}$ \\
\hline Oleic acid & & & & 1 & 0.011 & 0.159 \\
\hline Linolenic acid & & & & & 1 & 0.098 \\
\hline Erucic acid & & & & & & 1 \\
\hline
\end{tabular}




\section{Conclusions}

It is concluded from the above results that highly significant variations were observed for all the bio-chemical parameters. Highest heritability and selection response were recorded for glucosinulate content followed by erucic acid content while lowest heritability and selection response were obtained for oleic acid content. Oil content showed negative associations with protein content, glucosinulate content and erucic acid content, while rest of all the associations were positively associated with each other. Genotypes 606 (oil content), 619 (protein content) and 603(oleic acid and linolenic acid contents) were superior, while genotypes 617 (glucosionalte content) and 615 (erucic acid content) were inferior and should be recommended for use in future breeding programs.

\section{Authors' contributions}

Conceived and designed the experiments: Fawad Ali, Junaid Khan, Performed the experiments: Haneef Raza, Ijaz Naeem, Analyzed the data: Murad Khan, Naila Nawaz Khan, contributed reagents/materials/analysis tools: Anwar Rashid, Mohammad Wasiullah Khan, Wrote the Paper: Jawad Ali, Abdul Saboor Khan

\section{References}

1.Rakow G (2004). Species origin and economic importance of Brassica. In: Biotech.in Agric and Fores (Eds.): E.C. Pua and C.J. Douglas 54: 3-11.

2.Warwick SI, Francis A \& Al-Shehbaz IA (2006). Brassicaceae species checklist and database on CD-Rom. Pl Syst Evo 259: 249-258.

3. Khatri A, Khan IA, Siddiqui MA, Raza S \& Nizamani GS (2005). Evaluation of high yielding mutants of (Brassica juncea L.) cv. S-9 developed through Gamma rays and EMS. Pak J Bot 37(2): 279-284.

4.Becker HC, Loptien H \& Robbelen G (1999). Breeding: An overview. In: Biology of Brassica Coenospecies. (Ed.): C. GòmezCampo, Elsevier, Amsterdam pp. 413-460.
5. Shengwu H, Ovesna J, Kucera L, Kucera V \& Vyvadilova M (2003). Evaluation of genetic diversity of Brassica napus germplasm from China and Europe assessed by RAPD markers. Plant Soil Environ 49(3): 106-113.

6.Aytac Z \& Kinaci G (2009). Genetic variability and association studies of some quantitative characters in winter rapeseed (B. napus L.). Afr. J Biotechnol 8(15): 3547-3554.

7.Akbar M, Mahmood T, Yaqub M, Anwar M, Ali M \& Iqbal N (2003). Variability, correlation and path coefficient studies in summer mustard (B. juncea L.). Asian $J$ Plant Sci 2(9): 696-698.

8. Sadat HA, Nematzadeh GA, Jelodar NB \& Chapi OG (2010). Genetic evaluation of yield and yield components at advanced generations in rapeseed (B. napus L.). Afr J Agric Res 5(15): 1958-1964.

9.Iqbal S, Farhatullah, shah S, Kanwal M, Fayyaz L \& Afzal M (2014). Genetic variability and heritability studies in indigenous brassica rapa accessions. Pak J Bot 46(2): 609-612.

10. Gomez KA \& Gomez AA (1984). Statistical procedures for agricultural research. $2^{\text {nd }}$ Edition.John Wiley \& Sons, New York, USA.

11. Panse VG \& Sukhatme PV (1967). Statistical Methods for Agricultural Workers.Indian Council of Agricultural Research, New Delhi.

12. Fehr WR (1993). Principles of cultivar development: Vol. I. Theory and techniques. McMillan Pub Co USA.

13. Tuncturk M \& Ciftci V (2007). Relationships between yield and some yield components in rapeseed (Brassica napus L.) cultivars by using correlation and path analysis. Pak J Bot 39(1): 81-84.

14. Khan S, Farhatullah, Khalil IH, Khan MY \& Ali N (2008). Genetic variability, Heritability and correlation for some quality traits in $\mathrm{F}_{3: 4}$ brassica populations. Sarhad J Agric 24(2): 223-231.

15. Rameeh V, Saeidi G \& Rezai A (2003). Path coefficient analysis for agronomic traits and yield components in rapeseed. 
Proceedings of the Fourth Intl. Iran \& Russia Conference. 310-310.

16. Ping S, Mailer RJ, Galwey N \& Turner DW (2003). Influence of genotype and environment on oil and protein concentrations of canola (Brassica napus L.) grown across southern Australia. Australian Journal of Agriculture Research 54(4): 397-407.

17. Khan FA, Ali S, Shakeel A, Saeed \& Abbas $\mathrm{G}$ (2006). Genetic variability and genetic advance analysis for some morphological traits in (Brassica napus L). J Agric Res 44(2): 83-88.

18. Alemayehu N \& Becker H (2002). Genotypic diversity and patterns of variation in a germplasm material of Ethiopian mustard (Brassica carinata A. Braun). Genetic Resources and Crop Evolution 49: 573-582.

19. Turi NA, Farhatullah, Rabbani MA \& Shinwar ZK (2012). Genetic diversity in the locally collected brassica species of Pakistan based on microsatellite markers. Pak J Bot 44(3): 1029-1035.

20. Azam SM, Farhatullah, Nasim A, Shah S \& Iqbal S (2013). Correlation studies for some agronomic and quality traits in brassica napus L. Sarhad J. Agric 29(4): 547-550.

21. Bhardwaj HL \& Hamama AA (2000). Oil, erucic acid and glucosinlate contents in winter hardy rapeseed germplasms. Ind. Crops Products 12: 33-38.

22. Islam MSL, Rahman \& Alam MS (2009). Correlation and path coefficient analysis in fat and fatty acids of rapeseed and mustard. Bangladesh J Agric Res 34(2): 247-253.

23. Ahmad B, Mohammad S, Farooq-i-Azam, Ali I, Ali J \& Saeedur Rehman (2013). Studies of genetic variability, heritability and phenotypic correlations of some qualitative traits in advance mutant lines of winter rapeseed (Brassica napus L.). American-Eurasian J Agric \& Environ Sci 13(4): 531-538.

24. Hu ZL (1988). A genetic analysis of qualitative characters in rapeseed (Brassica napus L.). Cruciferae Newsletter. pp. 13-58.

25. Schierholt A \& Becker HC (2001). Environmental variability and heritability of high oleic acid content in winter oilseed rape. Plt. Breed 120(1): 63-71.

26. Velasco L, Goffman DF \& Becker HC (1998). Variability for the fatty acid composition of the seed oil in a germplasm collection of the genus Brassica. Genetic Resources and Crop Evoluation 45: 371-382.

27. Alemayehu N, Becker \& Heiko (2005). Quantitative genetic analysis of total GSL, oil and protein contents in Ethiopian mustard (B. carinata L.). Ethiopian J Sci 28(2): 141-150.

28. Abideen SN, Nadeem F \& Abideen SA (2013). Genetic variability and correlation studies in Brassica napus L. genotypes. International Journal of Innovation and Applied Studies 2(4): 574-581.

29. Mandal S, Yadav S, Singh R, Begum G, Suneja P \& Singh M (2002). Correlation studies on oil content and fatty acid profile of some Cruciferous species. Genetic Resources and Crop Evoluation 49(6): 551-556.

30. Ahmad M, Naeem M \& Khan IA (2013). Relative abundance of aphids' population on different brassica genotypes. Sarhad J Agric 29(1): 133-138.

31. Patel PJ \& Vyas SR (2011). Heritability and genetic advance for yield and quality traits in Indian mustard [Brassica juncea (L.) Czern and Coss. Adv Res J Crop Improv 2(2): 212-214. 